\title{
Alimentación, nutrición y hábitos sanos en el crecimiento de los niños de 3 a 4 años
}

\author{
Food, nutrition and healthy habits in the growth of children from 3 to 4 \\ years old
}

1 Héctor E. Hurtado-Puga

https://orcid.org/0000-0002-9038-6108

Universidad Técnica de Ambato, Facultad de Ciencias Humanas y de la Educación, Carrera de Educación Inicial. Ambato, Ecuador,

hectorehurtado@uta.edu.ec

2 Dorys Cumbe-Coraizaca

(iD) https://orcid.org/0000-0003-1818-5974

Universidad Técnica de Ambato, Facultad de Ciencias Humanas y de la Educación, Carrera de Pedagogía de los Idiomas Nacionales y Extranjeros. Ambato, Ecuador, dm.cumbe@uta.edu.ec

3 Jimena Paola Mantilla García (iD) https://orcid.org/0000-0002-2484-3163 Universidad Técnica de Ambato, Facultad de Ciencias Humanas y de la Educación, Carrera de Educación Inicial. Ambato, Ecuador, jimenapmantilla@uta.edu.ec

4 Daniela Benalcázar Chicaiza iD https://orcid.org/0000-0003-1990-634X. Universidad Técnica de Ambato, Facultad de Ciencias Humanas y de la Educación, Carrera de Educación Inicial. Ambato, Ecuador, da.benalcazar@uta.edu.ec

Artículo de Investigación Científica y Tecnológica Enviado: 24/12/2021

Revisado: 29/12/2021

Aceptado: $12 / 01 / 2022$

Publicado:08/03/2023

DOI: https://doi.org/10.33262/concienciadigital.v6i1.4.1990

Cítese: $\quad$ Hurtado Puga, H. E., Cumbe Coraizaca, D., Mantilla García, J. P., \& Benalcázar Chicaiza, D. (2023). Alimentación, nutrición y hábitos sanos en el crecimiento de los niños de 3 a 4 años. ConcienciaDigital, 6(1.4), 123-140. https://doi.org/10.33262/concienciadigital.v6i1.4.1990

\footnotetext{
CONCIENCIA DIGITAL, es una Revista Multidisciplinar, Trimestral, que se publicará en soporte electrónico tiene como misión contribuir a la formación de profesionales competentes con visión humanística y crítica que sean capaces de exponer sus resultados investigativos y científicos en la misma medida que se promueva mediante su intervención cambios positivos en la sociedad. https://concienciadigital.org .

La revista es editada por la Editorial Ciencia Digital (Editorial de prestigio registrada en la Cámara Ecuatoriana de Libro con No de Afiliación 663) www.celibro.org.ec 


\section{Palabras}

\section{claves:}

nutrición, salud, alimentación saludable, crecimiento infantil, guía nutricional.

\section{Keywords:}

nutrition, health, healthy eating, child growth, nutritional guide.

\section{Resumen}

En esta investigación se evidencia que, como parte de un nuevo estándar de salud global, busca crear nuevos estilos de vida saludables que mejoren la calidad de vida de las personas. El objetivo de esta investigación es definir los alimentos que los niños necesitan para un crecimientos adecuado; basado en esta preocupación la investigación se traslada a un proceso de dos partes: la primera comienza con la compilación de información confiable basada en expertos e inicia el tema propuesto, un estudio de caso de la herencia culinaria del Ecuador, y por otro lado para ayudar a mejorar la riqueza alimentaria de nuestro país y los beneficios que puede ofrecer, en el segundo paso, se desarrolló un análisis teórico y práctico, la búsqueda de datos reales para verificar la hipótesis: alimentación, nutricio y hábitos sanos mejoran el crecimiento de los niños de 3 a 4 años, con un método de trabajo aplicable a un cuestionario para niños del grupo de edad antes mencionado, un Mapa de Crecimiento Infantil y el registro de la nutrición basado en alimentos del Ecuador, y para concluir pero al mismo tiempo brindar un punto de partida hacia una propuesta nutricional innovadora para los niños, se desarrolla una guía de nutrición que no es más que un resumen de la investigación. La finalidad de la investigación se centra en la preparación de platos de manera creativa, con los ingredientes adecuados, preparados en las porciones, y mezclas correctas para los niños.

\section{Abstract}

This research shows that as part of a new global health standard, it seeks to create new healthy lifestyles that improve people's quality of life. The objective of this research is to define the foods that children need for adequate growth; Based on this concern, the research moves to a two-part process: the first begins with the compilation of reliable information based on experts and begins the proposed topic, a case study of the culinary heritage of Ecuador, and on the other hand to help to improve the nutritional wealth of our country and the benefits it can offer, in the second step, a theoretical and practical analysis was developed, the search for real data to verify the hypothesis: food, nutrition and healthy habits improve the growth of children from 3 to 4 years, with a work method applicable to a questionnaire for children of the aforementioned age group, a 
Child Growth Map and the food-based nutrition registry of Ecuador, and to conclude but at the same time provide a starting point towards an innovative nutritional proposal for children, a nutrition guide is developed that is nothing more than a summary of the research. The purpose of the research focuses on creatively prepared dishes, with the right ingredients, prepared in the right portions, and mixes right for children.

\section{Introduction}

The present research, taking nutrition into account, refers to Ratner et al. (2017), who primarily point to nutritional cultures as contexts of triggering towards a good lifestyle, that is, to carry out a good practice of habits that They favor our health and towards a bad lifestyle that refers to activities that are harmful to the human body, the portions in which we eat, the food groups that we prioritize, the knowledge about which portions we want to eat, are aspects that must be take into account for its study and good discernment, knowledge about nutrition also allows to clarify the nutritional importance within the first years of life and schooling, in terms of Arrunátegui (2016), hey conclude in their research carried out in a neighboring country Peru, where lifestyles, nutritional standards and population characteristics do not vary to a greater degree compared to Our nation, that those children who come from rural sectors are few cases that have an optimal healthy state of life in terms of a large percentage have degrees of malnutrition and as a consequence diseases that will appear immediately or in their adult life, as well also the other reality of urban sectors where child overweight was evidenced to a considerable percentage as a result of bad eating habits, mismatches when organizing time and the invasion of new technologies.

Knowing about nutrition and the indices of health problems that can trigger invites us to think about the importance of optimal growth from childhood (Benjumea et al., 2017), its delay is due to an important factor present between the stage of pregnancy and the first two years of life: an inadequate diet, if the aforementioned is given in continuity, will bring as a consequence and fruits a number of health problems not only physically visible due to lack of height or due to shortness or height weight, also affects two of the four vital areas of development for the child, such as cognitive and language, both can be evidenced by their progress or decline in the child's school performance accompanied in the same way in their social and affective development with the others people. Gómez et al. (2016), group their study in the main role that the authorities of each country, town or community keep towards the realization of public policies in favor of growing with health, with not only unitary purposes nor for a certain case study, but that they are global for everyone 
who has interests in contributing to the development of the human being in all its forms and lifestyles.

Nutrition with a focus on social change is where inquiry prevails (Zafra, 2017), to clarify that food can not only be seen as a necessary entity for the body similarly, it is a form of expression in terms of what we think, We feel and how we act, nutritional education is not knowing theoretically about terms concerning the subject, but rather it is acting in an autonomous, real way, that the student feels and lives more autonomously, that their nutritional needs grow based on their tastes and culture, The same article ends by putting food culture as a powerful sender of language between nations worldwide, due to what colloquially unite inclusive lifestyles that enjoy the gastronomic variety that can be found from soils with little wealth in nutrients and minerals that is one of the great social challenges today.

The new demands of this century, take an interest in combating this problem for the same reason Nur \& Arriaga (2016), talk about the nutritional education programs aimed at ages 3 to 12 years old where, they work in the Raising awareness playfully with families and schools, among its objectives is to change the mentality of the old or traditional diet through creativity in the kitchen, putting into practice gastronomy skills has allowed increasing the consumption of healthy foods such as fruits and vegetables in portions improved, after highlighting this social program, it is pertinent to show the results based on a critical evaluation where the main problem is the inadequate implementation of said nutritional plan, that is, we find deficits in terms of the importance of quality and not of amount, the personnel to whom it is hired, as directed by the community or school authorities, in terms of the excess AI, accessibility and management of the same (O Abeyá, 2016).

Cortés (2016), contributes with knowledge about agri-food systems that rediscover those who are not taken with the main role that should be those producers, those agricultural people who make possible the production, commercialization and optimal care of the products natural products that we can find in various markets where not a physical product is offered but the reality that is kept behind said people who are dedicated to planting and harvesting, where their economic source is the natural environment, the cultural descent from generation to generation It has provided them with a profession and a fruitful economic source, not only for the aforementioned benefits but also for the vital contribution to human life, economic realities, climate changes are a disadvantage of these systems, for this it is also an important study to fight due to the increase in said productivity, due to its resources and human talent.

In the variable Ecuadorian food heritage, it is first analyzed in a general way (Salazar, 2016), that the Ecuadorian state for some years has sought to give another meaning to the policies it manages based on nutrition, health, food, among others, for sectors of greater 
vulnerability and for the ages that range from childhood to adult life, it is interesting to emphasize the qualities that characterize Ecuador, a small country but rich in biodiversity, flora and fauna that is committed to a policy of good living that narrows and links new ways of life, a country with equity for all, being a nation that has adequate food resources, the problem for sure lies in another area, the lack of knowledge about what can be found in their lands and the inadequate distribution of their products to all their spaces.

Within the articles in force in the Constitution of Ecuador, food is called a right that must be promoted by the state itself, poorly applied strategies can be a deterioration in terms of the export of our products and generate negative aspects such as dependence in any area, proactive solutions are immediate actions that must be carried out for the same reason (Franco, 2016), commitment to food sovereignty where what is ours is strengthened and revalued, also speaking of our worker resource, the new administrations in distribution of food for everyone, not wasting it, knowledge about food culture is nothing more than a power at the national level about what we have and how we can achieve great things with a simple change towards the way of mentalizing ourselves about something or someone.

The gastronomic heritage of Ecuadorians depends on the region in which it is located, each one of them is differentiated by its aromas, beliefs and its people (Andrade y Ruperti, 2016), the Ecuadorian nutritional diet focuses on obtaining the greatest sources of energy at lunch, followed by a snack and finally breakfast, food intake, demand for typical dishes of each region, and palate preferences, beef, white meat, chicken, pork, it is worth mentioning They are another food source, the use of oils that provide fats that are not so healthy for the human body is another source present in the country's diet, the consumption of natural carbohydrates is also evidenced in rice, potatoes, cassava, noodles, among others, There is no general pyramid for everyone at the national level due to the few scientific contributions on this topic, but if a percentage of what Ecuadorians consume when choosing what they want to eat can be given, lime of the people emits good energy and once again takes into account that nutrition is not only a state of health but also a means of communication and a tourist power of that Ecuador has.

The Ecuadorian gastronomic wealth as a bridge towards the cultural and tourist identity worldwide is another contribution of Torres et al. (2017), which highlights the exaltation of a new phenomenon of the XXI century, which attracts foreign tourists and from neighboring towns, where the main need is to delight their palates with the cuisine of this country (Maldonado et al., 2017), they do not want to overlook naming those kitchen experts who based on their experiences of life, they know that within the culinary world they experience various points of view, ways of thinking, tastes in flavors, colors, placement of dishes, portions, hygiene, success in Ecuadorian food focuses on the revaluation and rescue of tradition years ago with the innovations of the new experts in 
the kitchens who carry out their studies abroad and become great chefs, restaurant managers, and even touristic human powers that $\mathrm{s}$ they are recipients of what can be found in our lands.

The food heritage of indigenous peoples (Campos \& Favila, 2018) is interrelated with the identity of a people and the increase in visits by tourists that it may have behind a typical plate of food, some experiences, forms are saved of life individual perceptions, coexistence between peoples. Now Fernández et al. (2016), highlights something similar that happens with the food heritage of our indigenous peoples, as a self- identification that invites the exploration of unpublished Delights of the senses: taste, smell, sight, touch, hearing, and the application of new skills within the culinary art, healthy nutrition is another recognition that Canchina (2016), makes towards indigenous cultures that are 18 in our country divided into the four regions: Coast, Sierra, Orient and Galapagos, each one of them the only thing they want to save, are their unique and untouchable resources for their future generations. those who are interested in safeguarding the importance of conserving their natural assets, their ethnic riches, and the diversity of food that we can find.

Within the national context it is quite broad to discern or list all the food goods that we can find depending on the soil in which we find ourselves. Moya (s. f.), puts as a reference the Sierra region in which despite its extension and in each In the corner where they live, the difference in consumption is not very significant, among their natural productions we can find, in grains: broad beans, corn, beans, lentils, brown, in legumes and vegetables: lettuce, carrots, cabbage, beet, onion, among the meats: guinea pig, rabbit, cow, lamb, horse, hen, at the same time we add the processed foods that intervene the hand of man where we can no longer find a source of Protein necessary for our nutritional diet, natural drinks and commercial juices today, is the whole conglomerate of combinations that make what results in the loss of adequate energy value for our body, ex lack or low consumption of certain foods.

Machado et al. (2016), talk about health experts who argue that living healthily is a virtue that must come from people innately as a consequence of habits and routines of conservation towards the Intake of healthy foods and is a weapon against diseases such as diabetes, high cholesterol, among others, the joint work of experts who are interested in the subject, people steeped in the nutritional world and entire conglomerates eager to improve their styles of life. Freidin (2016), concludes his writing inviting us to deduce that the three functional schools to advance with the subject are: the family, the school, and the social context where we develop, the importance of the intake of appropriate food should not be quantified by quantity or by making an excuse for the economic level of the people, it is enough to know how to prioritize set objectives, set goals and what is desired for the body focused on health. 
The nutritional requirements that the child must ingest are connected, towards their daily activities and the control of what they eat during their daily work (Luna et al., 2018), the physical appearance of a child It is the result of its nutritional contribution that it makes or knows, its growth and development must have an interrelated connection nexus, it cannot be detached from each other. Chinea et al. (2017), they assume as the main mirror the birth of the child and the intake of breast milk during the first months of life, the contribution to the brain and all parts of the body are of great magnitude, comparing the nutritional value of a mother's milk with the well-known formula, we find normal growth during the first 5 years of life, those children who have been raised without any artificial help but in a natural way with the consumption of breast milk, their weight and height being consistent with age chronology, if we want healthy children in their integral development, encouraging them to practice caring for babies as it was done in the past should be a research challenge for everyone.

In Latin America, about education, public policies are shared that issue the same purposes, the ages of childhood, adolescence and older adults are prioritized, their health, care, growth and good hygiene practices, when a child goes to school it is a new beginning for him, a new stage in which his ability to adapt to the environment must prevail, it is the responsibility of the state to safeguard the state of nutrition and growth for all, offering school menus has been taking place in recent years, the nutritional dining room must pursue the nutrition standards that are sought at a general level, a plate of food must be optimally presented in quantity and quality, as confirmed Vergara et al. (2016), "The school canteen must satisfy quantitatively and qualitatively the daily needs of energy and nutrients of the child and adolescent population, thereby ensuring proper growth and development".

Nourishing yourself to grow in a healthy culture is an idea that must be pursued and made possible, the current demands, the new ways of life, have advanced a lot in terms of this global objective to be achieved, but the constant struggle that must be achieved must not be forgotten. gives new inventions of marketable food products, energy drinks, fast foods and more

A healthy lunch box is, another so notorious, current school project that is managed in educational entities, within the Ecuador context, starting with the fulfillment of a healthy life and the stable academic performance of preschool life, in the province of Tungurahua, Pelileo, at the Joaquín Arias school, another way of contributing to the topic is around the elaboration of different dishes to be induced in the lunch that the children take. Tarqui \& Alvarez (2018), they highlight that the idea comes to combat the childhood obesity and other cardiovascular problems that lead to an inadequate diet, where fats, oils, carbohydrates are consumed, among others, without measure or awareness of their intake, for this purpose they visualize this project as a playful, creative, interesting tool, to learn 
to eat healthy. Arévalo et al. (2017), analyzes the other side of reality the characteristics of those lunch boxes where the existence of vegetables and fruits is scarce, where the existence of diseases in the future may be more likely to exist, the problem was due to realities such as poor distribution of time, preference towards industrialized foods, food intake without portions or conditions.

The ideal dish, optimal in healthy portions, is the question of many people for this reason, Subero et al. (2017), assumes the following information as an essential part to know, how, when, and what to eat, our day should be organized by serving in the morning where the consumption of fruits should be $20 \%$, accompanied by some cereal that is equivalent to $40 \%$, protein that is another $20 \%$ and a drink made from a natural source, portions of midmorning eat a $20 \%$ portion of fruit, lunch where $50 \%$ of our daily energy should be obtained, accompanied by vegetables, protein, and a carbohydrate in a minimum portion, in the afternoon another intake of something light such as: fruit, some whole grain cereal, and dinner where the consumption of $35 \%$ vegetables is prioritized and the rest in minimum portions can be some red, white meat, and that its cooking is medium. Freire et al. (2017), contributes to what has been said with the knowledge of seem nutritional gauging which is a strategy to help prevent what can be eaten at the right time, the colors that appear at a traffic light are the same as those used in this technique so that young and old can more easily discern what has been said, their values qualitative values are green, yellow and red while their quantifiable values are high, medium and low.

Rodriguez (2016) shows the graph, the green groups, proteins, and carbohydrates are the ones that should be ingested most frequently, the rest are taken as options for momentary tastings: carbohydrates from 4-6 servings a day, fruits and vegetables of $3-5$ servings a day, dairy products and derivatives of 3-4 daily servings, meats, eggs, sausages of 2-3 servings a day, other fatty foods 2-4 servings per week.

\section{Methodology}

It directs towards a descriptive inquiry of prospective transversality that visualizes the relationship that exists between nutrition and growth, prospective, since, when starting the study and analysis of the entire nutritional field and its benefits of taking it as a healthy habit, from Hence, in the future, the ingestion of dishes made from Ecuadorian products is proposed that, according to the desired requirements, contribute to the growth of human beings from an early age.

It is writing done in parts, starting from a qualitative approach as the basis of the ideas presented and the construction of a theoretical framework with subtopics such as: what is growth? How do you notice growth in people? What is it? nutrition? What is being healthy? What is being healthy? How can we eat healthily? How much can we eat? What is a food heritage? What are the appropriate portions to eat? What is food wealth in our 
country? Essentially, it is all provided to describe the independent variable: nutrition and the dependent variable: the Ecuadorian food heritage, it is also worth considering the quantitative, it is clear from the application of the instruments own for the deduction of all the information collected based on the synthesis and statistical application.

They are a question addressed to children from 3 to 4 years old directed to collect information on the dependent variable which is directed on nutrition in growth and in the same way the independent variable, which mentions the Ecuadorian food heritage, is also used for the purpose to obtain in the children their levels of agreement, the frequency with which they carry out a specific activity, the importance attributed to some factor, the assessment they give it for some things, the probability of some action in the future, its application will be of the most interactive way possible, with short, simple, objective questions that facilitate obtaining answers that are as close to reality as possible from the infants evaluated, as show in figure 1.

\section{Figure 1}

\section{Growth evaluation form for boys and girls}
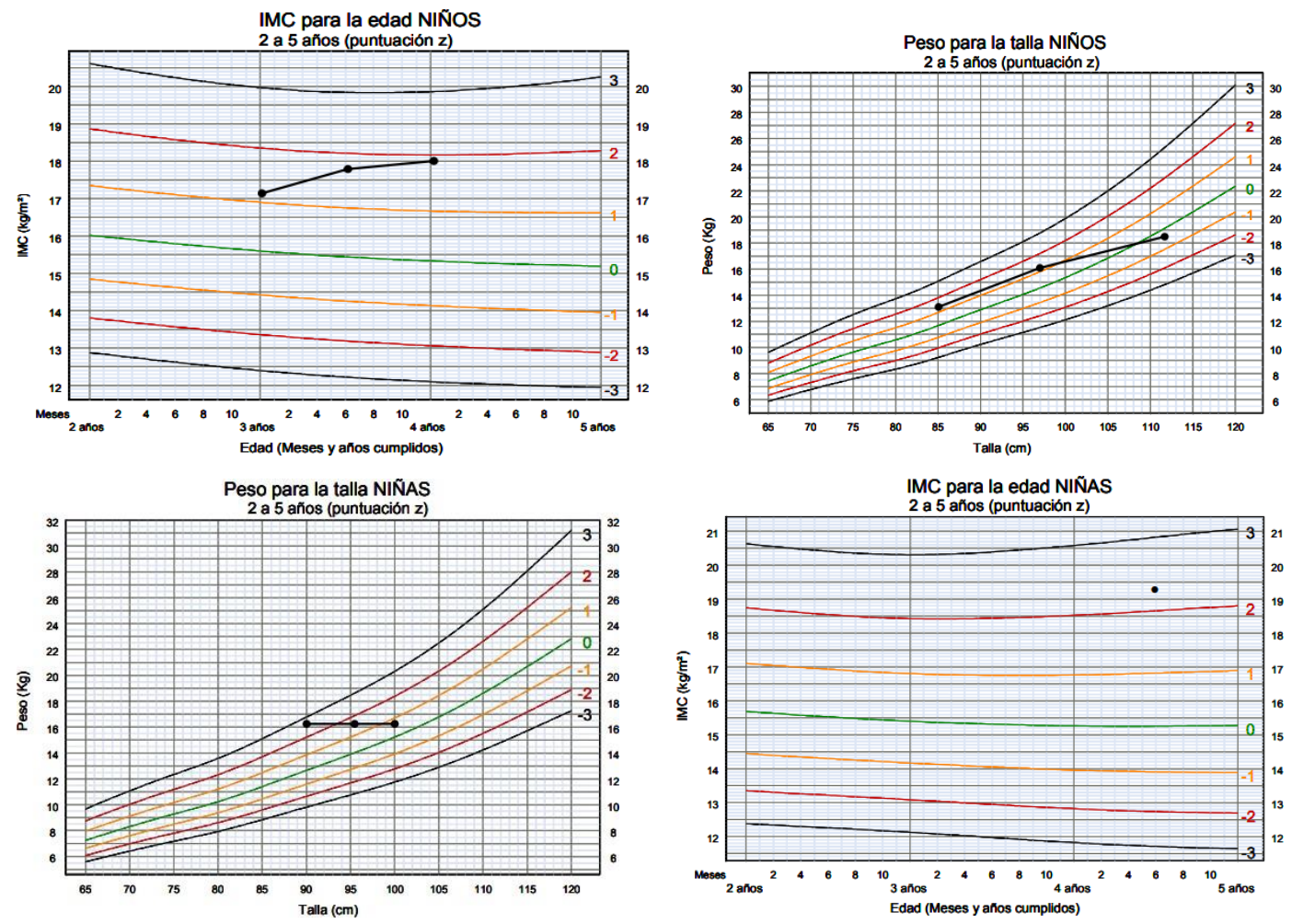

It was used to socialize the weight, height and body mass index of boys and girls according to their chronological age, thus evaluating the growth condition in which the studied population is found, specified and prioritized the different food groups: green foods, fruits or nuts, dairy products, red and white meats, carbohydrates, among others, 
which must be present in greater quantity in the recipe book to be tasted.

\section{Results}

For the development of the analysis of the results, the child growth sheet provided by the Ministry of Public Health was applied, which allowed obtaining the general growth table of the children of the CDI "Nuevo Amanecer", it was taken as the main reference to breaking it down through Statistical graphics that show the range of equality or inequality shown bythe child population according to Their height, weight and body mass index, to later correlate it with the Likert scale questionnaire focused on nutrition and foods they prefer to eat children in their daily days.

The table and graphs that were created using the information obtained by applying the child growth sheet are described below.

Table 1

Index of child growth of the children of the CDI "Nuevo Amanecer"

\begin{tabular}{|c|c|c|c|}
\hline $\mathrm{N}^{\circ}$ & Weight (Kg.) & Size $(\mathrm{cm})$. & I.M.C. \\
\hline 1 & 15,3 & 97 & 16,2 \\
\hline 2 & 15 & 95 & 16,6 \\
\hline 3 & 14 & 94 & 15,8 \\
\hline 4 & 13,5 & 96 & 14,6 \\
\hline 5 & 13,1 & 85 & 18,3 \\
\hline 6 & 13,3 & 92,5 & 15,4 \\
\hline 7 & 12 & 88 & 15,5 \\
\hline 8 & 16,2 & 100 & 16 \\
\hline 9 & 15,9 & 97 & 16,8 \\
\hline 10 & 18 & 102 & 17,3 \\
\hline 11 & 17,2 & 98 & 17,7 \\
\hline 12 & 13,4 & 93 & 15 \\
\hline 13 & 16,6 & 94 & 18,7 \\
\hline 14 & 16,6 & 98,5 & 17,1 \\
\hline 15 & 15,5 & 94 & 17,5 \\
\hline 16 & 13,4 & 88 & 17,9 \\
\hline
\end{tabular}


Table 1

Index of child growth of the children of the CDI "Nuevo Amanecer" (continuation)

\begin{tabular}{|c|c|c|c|}
\hline $\mathrm{N}^{\circ}$ & Weight (Kg.) & Size $(\mathrm{cm})$. & I.M.C. \\
\hline 17 & 15,8 & 93 & 17,3 \\
\hline 18 & 14,4 & 95 & 15,9 \\
\hline 19 & 17,5 & 90 & 21,6 \\
\hline 20 & 17,2 & 94 & 19,4 \\
\hline 21 & 15,7 & 100 & 15,7 \\
\hline 22 & 14,4 & 89 & 18,8 \\
\hline 23 & 16 & 96 & 17,4 \\
\hline 24 & 18 & 94 & 20,4 \\
\hline 25 & 14,9 & 95 & 16,5 \\
\hline 26 & 20 & 107 & 17,7 \\
\hline 27 & 16,5 & 101 & 16 \\
\hline 28 & 16,2 & 101 & 15,8 \\
\hline 29 & 16,5 & 95 & 18,2 \\
\hline 30 & 18,7 & 100 & 18,7 \\
\hline 31 & 16,7 & 99 & 17 \\
\hline 32 & 16,7 & 101 & 16,3 \\
\hline 33 & 15,6 & 101 & 15,2 \\
\hline 34 & 16,3 & 96 & 17,6 \\
\hline 35 & 15,1 & 94 & 17 \\
\hline
\end{tabular}

Of the 35 children that correspond to $100 \%$ of the population, the following measurements were taken in height, weight and body mass, which show the range of proportionality in all the children studied, it can also be seen that what corresponds to weight in kilograms, the lowest measurement is 12 and the highest is 20 , which allows a normal range to be called in this regard, followed by the average height in centimeters where the shortest size is considered 85 and the highest size 107, which allows designating a range of difference no greater than $10 \%$ in this regard, to finish what refers to the study of the body mass index is calculated by means of a mathematical operation 
dividing the kilograms of weight by the square of the height In centimeters of each student where 14, 6 is considered the lowest BMI and 21.6 is considered the highest BMI, which is why all children can be defined in a normal range of no more than $15 \%$.

Figure 2

Weight in kilograms of the children of the CDI "Nuevo Amanecer"

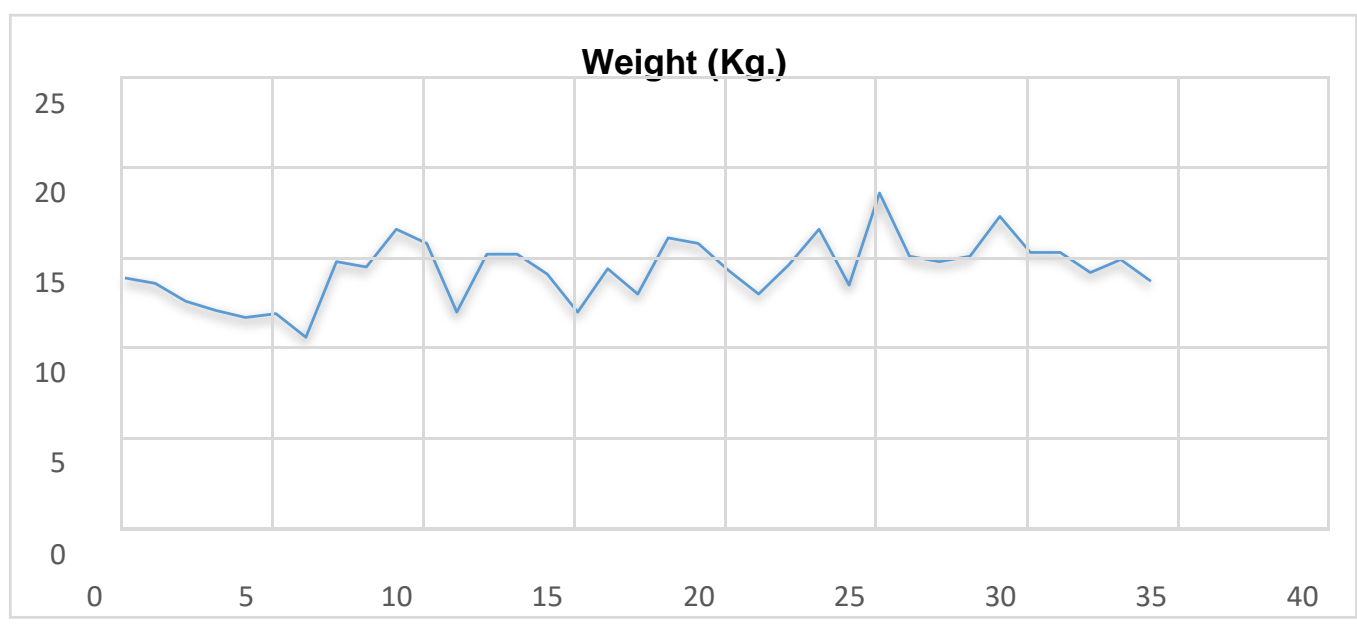

Of the 35 children studied that corresponds to $100 \%$, a general analysis of their weight in kilograms was carried out, for which a statistical graph was used, where we can visualize that it indicates as $12 \mathrm{~kg}$ the lowest weight and on the other hand the most weight; high has a value of $20 \mathrm{~kg}$, these references allow to corroborate that in their totality the weight of the children does not vary in large measures and it can be defined that they are in a normal range in terms of this growth measure.

\section{Figure 3}

Size in centimeters of the children of the CDI "Nuevo Amanecer"

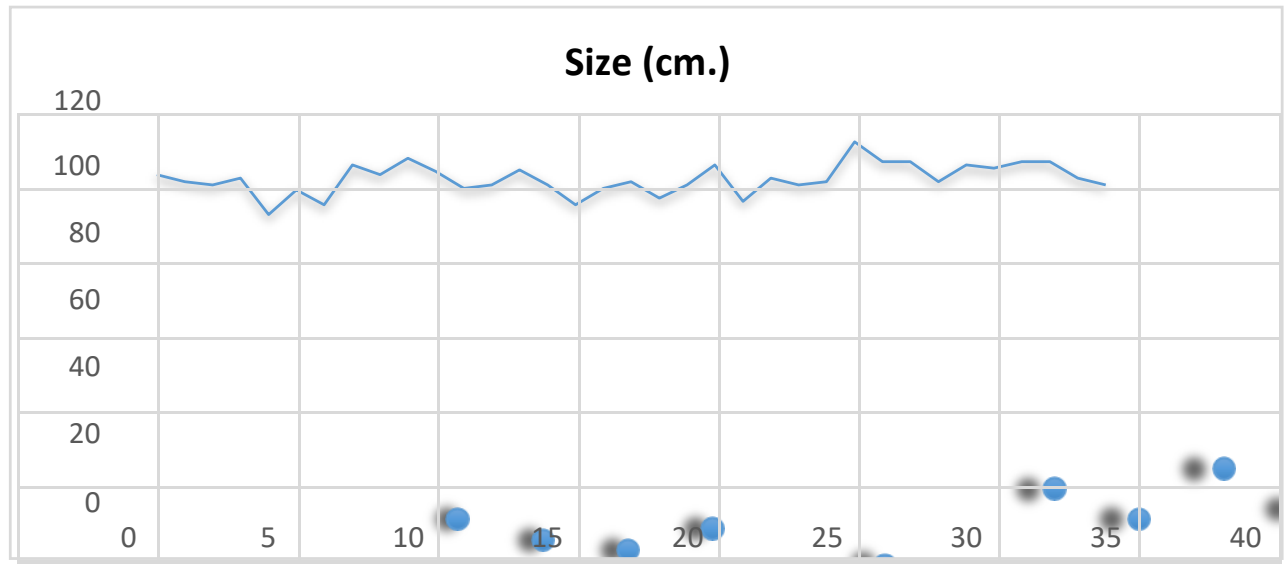


Of the 35 children studied that corresponds to $100 \%$, a general analysis of their height in centimeters was carried out, for which a statistical graph was used, where we can visualize that it indicates the lowest weight as $85 \mathrm{~cm}$ and on the other hand the highest weight has a value of $107 \mathrm{~cm}$, these references allow to corroborate that in their totality the height of the children between the lowest and the highest does not have a difference greater than $10 \%$, which affirms that within this measure of growth there is not much variation among all children analyzed.

\section{Figure 4}

Body mass index of the children of the CDI "Nuevo Amanecer"

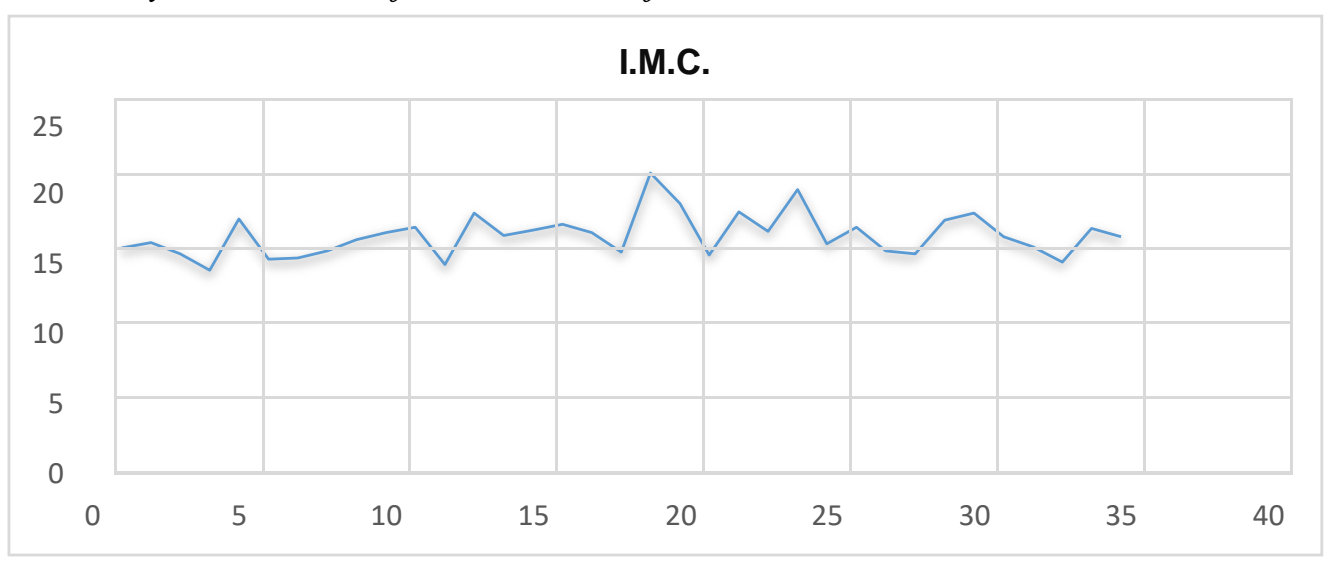

Of the 35 children studied that corresponds to $100 \%$, a general analysis of their height in centimeters was carried out, for which a statistical graph was used, where we can visualize that it indicates the lowest weight as $85 \mathrm{~cm}$ and on the other hand the highest weight has a value of $107 \mathrm{~cm}$, these references allow to corroborate that in their totality the height of the children between the lowest and the highest does not have a difference greater than $10 \%$, which affirms that within this measure of growth there is not much variation among all children analyzed.

Figure 5

Growth rate of the children of the CDI "Nuevo Amanecer"

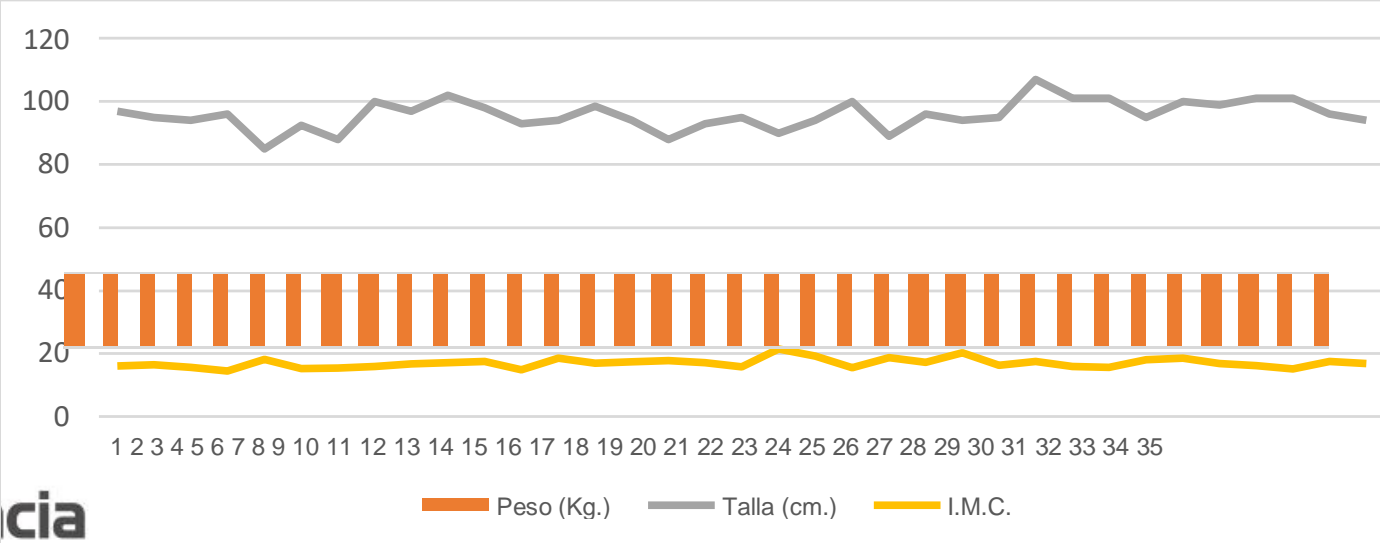


Of the 35 children studied that corresponds to $100 \%$, after analyzing their height, weight and body mass is where it is possible to obtain the statistical graph of the growth of all children, where we can observe that according to the age of 3 to 4 years The variations that we can find are minimal, and they go according to their chronological age, there are greater changes in measurements between the one year difference that exists between the chosen population, hence it allows us to affirm that the children of the CDI "Nuevo Amanecer" according to the requirements established by the child growth sheet are in proportional levels that define a normal range of growth.

\section{Conclusions}

- Children's nutritional nutrition is undoubtedly the correct and varied combination of all food groups: proteins, vegetables, fruits, grains, dairy products, saturated fats, among others, which can be found within the Ecuadorian food heritage, on the other hand it is a mirror that reflects the gradual growth of children from an early age, with their weight and height appropriate to their chronological age, a healthy child in body and mind is ready for greater knowledge and social development with others, therefore, there lies the importance of keeping up with knowledge about nutrition and the consequences that it entails if we decide to apply it in our daily lives and show it by changes in eating habits, such as: eat at an appropriate time, eat slowly, eat 5 times a day in balanced portions, eat slowly, combine foods correctly, learn about the variety of natural products that exist around us Or and most importantly, do what is said not out of obligation but as a habit present in daily life.

- Since with the research it has been possible to know the classification of the food groups present in our natural environment and their benefits in minerals such as iron, zinc, magnesium, potassium, sodium, phosphorus, those mentioned stand out among the most important something similar happens with vitamins: VA, VE and VC. It sounds coherent that what has been said is used according to both the physical and intellectual needs that the infant requires, in terms of protein: once a day (140gr), fruit: 3 times a day, carbohydrates: it can be potatoes, rice or pasta ( 2 times a day), vegetables (50gr) 2-3 times a day, white fish: 3 times a week, bluefish: 3 times a week, sweets: present on specific occasions and dairy products and their derivatives: can be Consumed between days, if the described is applied, the nutritional requirements will be met according to the age and physiological need of each person and more than that of a child.

\section{References Bibliographical}

Andrade, C., \& Ruperti, L. (2016). Una mirada. Republica de Ecuador. Revista científica dominio de las ciencias, 2(3), 55-66. 
file:///C:/Users/Erick/Downloads/Dialnet-UnaMiradaRepublicaDeEcuador5761596.pdf

Arévalo, L., Castro, S., \& García, G. E. (2017). Características de la lonchera del preescolar y conocimiento nutricional del cuidador: un estudio piloto en Lima, Perú, 2016. Revista chilena de pediatría, 88(2). https://scielo.conicyt.cl/scielo.php?script=sci_arttext\&pid=S037041062017000200019

Arrunátegui, V. (2016). Estado nutricional en niños menores de 5 años del distrito de San Marcos, Ancash, Perú. Revista Chilena de Nutrición, 43(2), 155-158. http://www.redalyc.org/pdf/469/46946547007.pdf

Benjumea, M., Parra, J., \& Jaramillos, J. (2017). Cómo intervenir y prevenir el retraso del crecimiento en niños menores de cinco años de hogares incluidos en el Sisbén de Caldas. Biomédica, 37(4). https://www.redalyc.org/jatsRepo/843/84354859011/html/index.html

Campos, A., \& Favila, H. (2018). Culturas alimentarias indígenas y turismo. Una aproximación a su estudio desde el control cultural. Estudios y Perspectivas en Turismo, 27(2). http://www.redalyc.org/jatsRepo/1807/180755394002/html/index.html

Canchina, A. (2016). Difusión del patrimonio alimentario de la nacionalidad Tsachila. http://dspace.udla.edu.ec/bitstream/33000/5478/1/UDLA-EC-TLG- 201618.pdf

Chinea, B., Awad, Y., Villarino, A. \& Sáenz, D. (2017). Beneficios a corto, medio y largo plazo de la ingesta de leche humana en recién nacidos. Nutrición Hospitalaria, $34(5)$,

1059-1066. https://www.redalyc.org/pdf/3092/309253341007.pdf

Cortés, I. (2016). La Crisis Alimentaria Mundial: causas y perspectivas para su entendimiento. Razón y Palabra, 20(94), 611-628. http://www.redalyc.org/pdf/1995/199547464036.pdf

Fernández, L., Rodríguez, Z., Pozo, J., \& Espinosa, J. (2016). Estrategias para el Fortalecimiento del Turismo Gastronómico en el Cantón. En E. E. Universidad Estatal Amazónica. http://DialnetEstrategiasParaElFortalecimientoDelTurismoGastrono-5761082\%20(1).pdf

Franco, E. (2016). El desperdicio de alimentos: una perspectiva desde los estudiantes de administración de empresas de la UPS Guayaquil. RETOS. Revista de Ciencias 

de
la
Administración
$y$
Economía,
$6(11)$ http://www.redalyc.org/jatsRepo/5045/504551173004/504551173004.pdf

Freidin, B. (2016). Alimentación y riesgos para la salud: visiones sobre la alimentación saludable y prácticas. Salud Colectiva, 12(4), 519-536. http://www.redalyc.org/pdf/731/73149180005.pdf

Freire, W. B., Waters, W. F., \& Rivas-Mariño, G. (2017). Semáforo nutricional de alimentos procesados: estudio cualitativo. Revista Peruana de Medicina $\begin{array}{lllll}\text { Experimental } \quad y \quad \text { Salud } \quad \text { Pública, } & 34(1), & \text { 11-18. }\end{array}$ http://www.redalyc.org/pdf/363/36350144003.pdf

Gómez, R., Arruda, M., Luarte, C., Albornoz, C., Almonacid, A., \& Cossio, M. (2016). Enfoque teórico del crecimiento físico de niños y adolescentes. Revista española de nutrición humana y dietética, 20(3), 87-110. https://dialnet.unirioja.es/servlet/articulo?codigo $=5643498$

Luna, J. A., Hernández, I., Rojas, A., \& Cadena, M. (2018). Estado nutricional y neurodesarrollo en la primera infancia. Revista Cubana de Salud Pública. http://scielo.sld.cu/scielo.php?script=sci_arttext\&pid=S086434662018000400169

Machado, K., Denis, N., Fernández, N., Migues, C., \& Pírez, C. (2016). Dificultades en la alimentación de niños sanos en Montevideo-Uruguay. Revista Chilena de Nutrición, 43(3), 228-232. http://www.redalyc.org/pdf/469/46947432001.pdf

Maldonado, C., Álvarez, J., Del Rio, M., \& Mora, V. (2017). Gastronomía creativa. file:///C:/Users/Erick/Downloads/Dialnet- GastronomiaCreativa-6733397.pdf

Moya, A. (s. f.). Altas Alimentario de los Pueblos Indígenas y. https://biblio.flacsoandes.edu.ec/catalog/resGet.php?resId=56270

Nur, A., \& Arriaga, A. (2016). Los elementos de efectividad de los programas de educación nutricional infantil: la educación nutricional culinaria y sus beneficios. Revista Española de Nutrición Humana y Dietética, 20(1). http://scielo.isciii.es/scielo.php?script=sci_arttext\&pid=S217451452016000100008

O Abeyá, E. (2016). Una evaluación crítica de los programas alimentarios en Argentina. Salud colectiva. https://www.scielosp.org/article/scol/2016.v12n4/589- 604/

Ratner, R., Hernández, P., Martel, J. \& Atalah, E. (1 de marzo de 2017). Propuesta de un nuevo índice de calidad global de la alimentación. Revista Chilena de Nutrición, 44, 33-38. http://www.redalyc.org/pdf/469/46950536005.pdf 
Rodríguez, P. (2016). El blog de tu bebé: https://www.elblogdetubebe.com/piramidealimenticia-ninos-sabes-interpretarla- correctamente/

Salazar, S. (enero, junio de 2016). Programas sociales de alimentación y nutrición del Estado ecuatoriano, estrategia. Economía, XLI (41), 76-96. http://www.redalyc.org/pdf/1956/195649910004.pdf

Subero, E., Mata, C., \& Hernández, P. (2017). Diseño del plato saludable y apreciaciones de los trabajadores sobre una jornada. Salud de los Trabajadores, 25(2), 138146. http://www.redalyc.org/pdf/3758/375855579004.pdf

Tarqui, C., \& Álvarez, D. (2018). Prevalencia de uso de loncheras saludables en escolares peruanos del nivel primario. Revista de Salud Publica. https://www.scielosp.org/article/rsap/2018.v20n3/319-325/\#

Torres, F., Romero, \& Viteri, M. (2017). Diversidad gastronómica y su aporte a la identidad cultural. Revista de la SEECI, ISSN-e 1576-3420, (44), 1-13. Obtenido de https://dialnet.unirioja.es/servlet/articulo?codigo $=6295958$

Vergara, D., Ríos, R., Úbeda, C., Escudero, M., \& Callejón. (2016). Menús ofertados en centros de educación infantil de Sevilla: adecuación a criterios. Nutrición Hospitalaria, 33(3), 671-677. http://www.redalyc.org/pdf/3092/309246400025.pdf

Zafra, E. (junio de 2017). Educación alimentaria: salud y cohesión social. Salud Colectiva. https://www.scielosp.org/scielo.php?pid=S1851$82652017000200295 \&$ script=sci_arttext\&tlng=en

\section{Ciencia Ligital}


El artículo que se publica es de exclusiva responsabilidad de los autores y no necesariamente reflejan el pensamiento de la Revista Conciencia Digital.

\section{Ciencia LDigital}

El artículo queda en propiedad de la revista y, por tanto, su publicación parcial y/o total en otro medio tiene que ser autorizado por el director de la Revista Conciencia Digital.
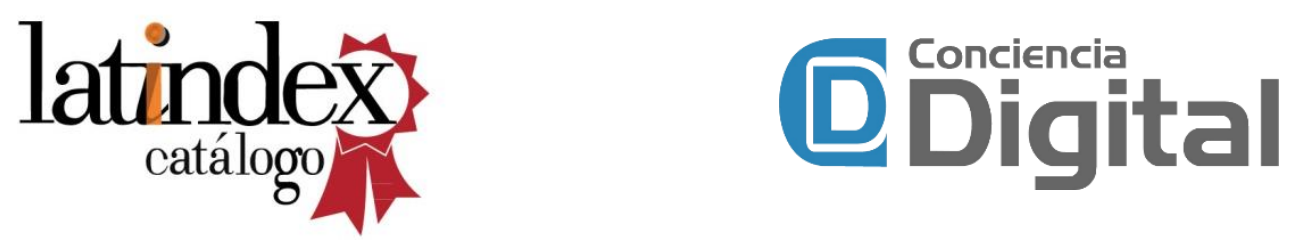

Indexaciones

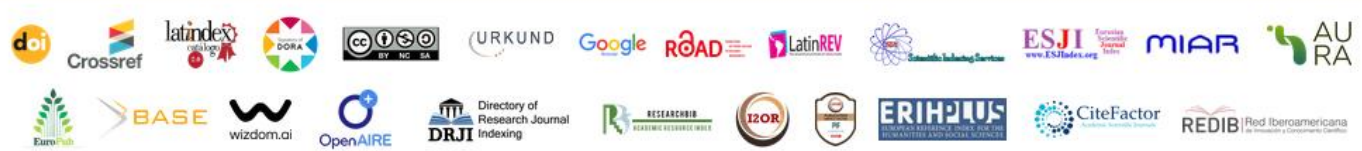

